\title{
A Nation-state without the nation? The trajectories of nation-formation in Montenegro ${ }^{1}$
}

\author{
SINIŠA MALEŠEVIĆ* and GORDANA UZELAC*** \\ *Department of Political Science and Sociology, National University \\ of Ireland, Galway \\ **Department of Sociology, London Metropolitan University, UK
}

\begin{abstract}
Following the successful referendum of May 2006, Montenegro became the last of the former Yugoslav republics to opt for an independent state. Only fifteen years earlier, when the Socialist Federal Republic of Yugoslavia collapsed, Montenegro was resolute to continue the Yugoslav state-formation in a union with Serbia. This paper attempts to answer the following questions: Why did it take so much longer for the Montenegrin population to follow the experience of other republics in its decision on independence? How can one explain a staggering change in public opinion on questions of national self-determination over such a short time-span? And, finally, what are the dominant discourses of "Montenegrin-ness"? The authors argue that the answers to these questions are to be found in the particularities of Montenegro's historical development, and especially in the structural legacies of state socialism. The consequence of these developments was the formation of two separate Montenegrin national ideologies: one which sees Montenegrins as ethnically Serb, and the other that defines Montenegrins in civic terms. The paper concludes that these two divergent trajectories of nation-formation in Montenegro are largely the unintended consequence of intensive state-building, cultural and political modernisation and, most of all, the gradual politicisation and institutionalisation of high culture.
\end{abstract}

KEYWORDS: Montenegro, nation-formation, state socialism.

\section{Introduction}

The collapse of communism as a social, political and economic order in the early 1990s was paralleled by the collapse of the state socialist model of federalism. The Soviet Union, Czechoslovakia, Yugoslavia and Ethiopia all disintegrated along federal lines as their former federal units became independent states. The only exception to this rule was the tiny South-east European state of Montenegro, which in 1992 held a referendum on its independence in which more than ninety per cent of its people decided to 
remain in the federal union with Serbia. It took another fourteen years to organise a second referendum in which the majority were in favour of independence, thus making Montenegro the last of the former state socialist federal units to become a sovereign, internationally recognised state. The three central and interrelated questions raised by this paper are: Why did it take much longer for the Montenegrin population to opt for independence than for the populations of other former communist states? How can one explain such a staggering change in public opinion on questions of national self-determination over what is, historically speaking, a very short period of time? And finally, what are the dominant discourses of 'Montenegrin-ness'?

In order to answer these three questions, we must explore a variety of social factors which could potentially have influenced this outcome. Our analysis recognises the importance of economic, political, cultural and historical variables in accounting for the direction of the nation-formation process in Montenegro. However, we argue that the most significant factors are to be found in the peculiar interplay between culture and politics; that is, in the politicisation and institutionalisation of culture that occurred under state socialism. In other words, we argue that it was under communist modernity that the institutional and organisational tracks which helped to structurally articulate the two competing forms of nation-building in Montenegro - the Serbian and the Montenegrin - were established. While the structures of state socialism provided the institutional framework for the crystallisation of this dual ethno-national diversity, it was recent geopolitical changes that coloured the content of the two nationalisms and that put the final nail in the coffin of the joint Serbian and Montenegrin state.

The paper is divided into four parts. First, we look briefly at the explanatory power of different social factors related to the question of the belated call for independence. Second, we concisely outline the historical trajectories of nation- and state-building in Montenegro from the late eighteenth century until the end of World War II. Third, we focus on the communist period and the role of state socialist modernity in shaping the ethno-political space. Finally, we direct our attention to current debates in the Montenegrin media on the question of 'Who are the Montenegrins?' in order to identify the form and content of the dominant discursive frames of nationhood in Montenegro today.

\section{The peculiarities of Montenegro's delayed independence}

As with any socio-historical phenomenon, the deferred ${ }^{2}$ popular call for Montenegrin independence is a result of a variety of social factors: historical legacies and internal political and geographical divides, financial dependence on the federal state and the economic debacle of the mid-1980s, the skewed and ambiguous relationship with Serbia, the complex military and heroic tradition of the Montenegrin tribes, the lack of substantial non-communist 
alternatives during the early years of transition, and the peculiarity of Montenegro's geopolitical position. While all of these and many other factors had a significant impact on the trajectory of social development in Montenegro, it is our contention that the most decisive explanation is to be found in the interplay between political and cultural factors. Specifically, we focus on the role of the communist state in fostering the processes that have intensified the institutionalisation and eventual politicisation of culture. However, before we articulate our argument it is important to evaluate the strengths and weaknesses of individual economic, cultural and political explanations.

Economic explanations stress the importance of objective, material considerations that precluded early calls for independence: the small size of the country $\left(13,812 \mathrm{~km}^{2}\right.$ with little over 600,000 inhabitants) and the alleged economic non-viability of an independent state that possessed few natural resources and had a chronic shortage of water (Gallagher 2003: 62). In addition, Montenegro's geographically landlocked situation between such impoverished countries as Albania, Macedonia and Kosovo further contributed to its weak, static and underdeveloped economy. The Yugoslav wars of the 1990s devastated an already weak financial system, cutting real GDP and industrial output to half of what it had been in 1990 (Đuric 2003: 141). Although economic factors do matter, they are clearly insufficient in accounting for the gradual change in popular attitudes towards independence. The Montenegrin economic system remains in worse shape than it had been in 1990, and has only slightly improved since 1992, but the change in popular attitudes towards independence over this same period has been astonishing: while in 1992 almost ninety-six per cent of population (with a turnout of sixtysix per cent) were in favour of union with Serbia, in the referendum of 2006 the population was firmly split in two with a slight majority in favour of independence. Economic motives alone cannot explain such an unprecedented change in social attitudes.

As even some Montenegrin economists recognise (i.e. Đurić 2003: 157), political factors seem to be more significant since the economic system often 'functioned as the hostage of politics'. The overtly political interpretations of the delayed calls for independence appear more solid. The early removal of the 'indigenous' Montenegrin communist leadership in favour of a proSerbian faction in January 1989, underpinned by the perception of a neighbouring external 'threat' in Kosovo and coupled with an extreme polarisation of politics along the East versus West axis in socialist Yugoslavia, had powerful adverse effects on the development of Montenegrin nationalism. The clear lack of articulated non-communist alternatives, ${ }^{3}$ the traditionally strong support for the Yugoslav military (where Montenegrin officers were highly overrepresented) and the specific geopolitical position of Montenegro meant that the wars of Yugoslav succession further helped unite the population of Montenegro around the new pro-Serbian leadership. A strong military presence, including the relocation of the entire Yugoslav navy fleet to the tiny Montenegrin coastal ports and the involvement of Montenegrin army 
reservists in the temporary occupation of Croatian territory around Dubrovnik, also strengthened Montenegro's traditional links with Serbia. All of these political events help us to understand how and why indigenous Montenegrin nationalism was institutionally stifled, but do not explain the peculiar direction that the nation-building process took in the late 1990s. Political factors alone cannot account for the hard and uncompromising schism between Montenegrin and Serbian nationalism today.

Finally, cultural factors have been identified as crucial to understanding the traditional weakness of a distinct Montenegrin nationalism. The fact that most Montenegrins nominally belong to the Serbian Orthodox Church, that the majority refer to their mother tongue as Serbian and write in Cyrillic script, and that they share many of what Anthony Smith (1999) would call common ethno-historical myths and memories (such as, for example, 'the Ottoman Yoke') suggests that the cultural and historical similarity between Montenegrins and Serbs has been the most influential social impediment to the development of an articulated and potent Montenegrin ideology of national self-determination. Although this perceived cultural similarity is fundamental to understanding the late calls for political independence, this has little if anything to do with any actual similarity between the two groups and more to do with the specific historical and institutional context that set the processes of politicisation of culture in motion. In other words, since any trans-historical cultural similarity of large collectivities is more mythical than real, and since cultures are dynamic processes rather than static categories, this alleged Serbian and Montenegrin similarity is highly problematic for a number of reasons.

First of all, as will be elaborated later, the collective designations of Serb, Montenegrin, Christian, Orthodox ${ }^{4}$ or specific tribal or clan-based names (i.e. Bjelopavlovići, Piperi, Kuči) were historically highly ambiguous, and rarely if ever mutually exclusive categories of identification. The fact that a particular nineteenth- or early twentieth-century peasant from the tribe of Bjelopavlovićs would describe herself as Serb (or Montenegrin or Christian) would not necessitate that she show any actual cultural resemblance or sense of attachment to a peasant in Serbia. On the contrary, she would probably resemble and identify more with an Albanian-speaking peasant from her own clan or tribe. Even if there was a nascent sense of Serbian/Montenegrin identification this does not mean that the actual cultural similarities existed on the ground as group loyalties remained predominantly articulated in a micro/ local (i.e. tribal or clan-based) rather than macro/national sense. While the (external) rhetoric of nationhood was occasionally present, it played little if any role in the actual everyday life of the peasantry.

Second, the actual cultural similarity argument ignores the significant difference between the North (Brda) and other regions incorporated only after the First Balkan War and the rest of Montenegro (Old Montenegro). As we will demonstrate, this socio-geographical divide between the two regions has never been fully transcended. Third, the emphasis on shared religion as a 
principal source of common identity between the two groups is problematic in both historical and current terms. As Pavlovic (2003b: 142) and long before him Rovinski (1998[1897]) show, church attendance was quite low and religious practice was at as non-observant a level in nineteenth-century Montenegro as it is in Montenegro today. Current Montenegrin society is predominantly secular, and the two leading political parties of the postcommunist era, the pro-Montenegrin PDS and the pro-Serb SNP, are both offshoots of the former Montenegrin League of Communists. Finally, hard cultural arguments, as with purely economic or political arguments, cannot explain the sudden outburst of Montenegrin nationalism since the late 1990s. To understand this development one must engage not with the static notion of trans-historical cultural unity but with the institutional, historical and sociological processes that initiated the politicisation of culture during the state socialist period. In other words, it is not culture or politics per se that matter; it is the peculiar interaction between the two that can explain the unusual social character of Montenegrin nation-formation. To fully comprehend the complexity of this process of nation-building, a brief overview of Montenegro's social history is required.

\section{A brief social history of Montenegro}

As the story goes, in 1766 a stranger came to the town of Maine. A year after his arrival he would become known as Ścepan Mali (Stephen the Little), the first and only 'Tsar' of Montenegro. The only 'credential' that put him on the throne and secured him the love of and authority over the common people and their leaders was a rumour that he was actually the Russian Tsar Peter the Third. In the seven years of his rule, Montenegrin tribes achieved a level of unity and peace that had never existed before (Jovanovic 1948: 134-50). This rather extraordinary event points towards important circumstances in the formation of Montenegrin society. It illustrates the complicated geopolitical position of Montenegrin lands, the complex social, political and economic structure of Montenegro and, above all, the rich history that would be appropriated as national history several centuries later.

The history of Montenegrin lands was to a great extent shaped by their distinctive geopolitical position. Historical records testify to the formation of Zeta as the first organised political entity in these territories. Zeta was shortlived and after 173 years of independent existence, in 1189 it became a semiautonomous section of a state ruled by the Nemanjic dynasty. The collapse of the Nemanjic dynasty in 1360 opened the door to the advance of a new power in the Balkans: the Ottomans. Over the next four centuries, Montenegrin history was marked by its position between the Ottomans and Venice. The Ottomans never gained full control over the lands of Montenegro. They managed to establish control over the main cities but found themselves incapable of maintaining a grip on the mountainous villages where the 
Orthodox population found refuge. This situation facilitated the formation of a specific social structure and culture for the people that lived in these territories.

Boehm (1983) has defined Montenegro as a segmentary society. The basic unit of Montenegrin society was the kuća (the house), a patrilocal extended family or a type of zadruga. Houses of unilinear descent usually formed a bratstvo (a clan, literally a brotherhood) over a relatively homogeneous territory with a strong sense of solidarity and group identity. Each bratstvo belonged to a pleme (tribe). Historical records refer to about twenty-one tribes of so-called Old Montenegro, and seven tribes of the Brda area (Rastoder 2003: 113). ${ }^{5}$ Inter-tribal issues were discussed in the All-Montenegrin Assembly. However, decisions of this assembly had only a moral obligation for the tribes as it possessed no executive organs. The Assembly elected and was chaired by the Vladika (the Metropolitan of the Montenegrin Orthodox Church). The Vladika served as both religious and secular leader of the Montenegrin tribes. This formally theocratic government lasted until 1852 when the Vladika Danilo proclaimed himself Prince and assumed a strictly secular role. At this time, Boehm (1983: 64) concludes, 'the identity and selfinterest of (the) individual Montenegrin was tied much more closely to his tribe, and to its jealously guarded autonomy, than to any idea of Montenegro as a whole'.

The episode of Ścepan Mali at the end of the eighteenth century marked a new beginning. The successive Vladikas - Petar I and Petar II Petrović Njegoš were determined to secure the internal unity of both Old Montenegro and the Brda tribes. In 1798 the Assembly devised the General Montenegrin and Hill Code to provide a legal basis, enforced by the Montenegrin and Hill Court and National Chancellery that resided in the capital, Cetinje (Rastoder 2003: 118). The first taxation system was established in 1833, backed by the institution of the (first) central police. A year later the first primary school and a monthly magazine in Montenegro were established. In 1852, Petar II's nephew Danilo formally separated secular from religious authority and established Montenegro as a principality. In 1853 he formed the first Montenegrin army and two years later issued the so-called Danilo's Legal Code.

Montenegro was formally recognised as an independent state at the Congress of Berlin in 1878. Prince Nikola concentrated on further consolidation of the central government, and in 1905 introduced the first Montenegrin constitution. The state was defined as a constitutional monarchy, and soon Montenegro witnessed the formation of its first political parties: Narodna stranka (the People's Party, better known as Klubaska, the Club Party) and Prava narodna stranka (the Real People's Party, better known as Pravaši). While the latter formed around support for the Montenegrin court, the former propagated closer ties with Serbia and Serbs. The opposition between these two parties was further radicalised after 1910 when Prince Nikola proclaimed Montenegro a Kingdom. 
The most important consequence of the 1912-13 Balkan Wars was a significant expansion of Montenegrin territory. In the wake of World War I, Montenegro acquired territories that had never before been a part of Montenegro, and a population with divided loyalties. After a few initial successes, Austria-Hungary occupied Montenegro in late 1915. The King and his government left the country and the Montenegrin Army officially surrendered. It was the Serbian Army that officially liberated and therefore effectively controlled Montenegro in 1918. The end of the war marked the beginning of the formation of a unified South Slav state. When this new state incorporated the territories of Montenegro, Montenegro ceased to exist as a political entity. An election for the so-called Grand National Assembly was organised, and on 26 November 1918 this parliament dethroned its king and accepted unconditional unification with the Kingdom of Serbia.

The division of loyalties between political and cultural elites in Montenegro was from now on to be recognised 'in colour', based on the colour of the paper on which the lists of candidates for the Assembly was printed. The supporters of unification were known as Bjelaši (Whites) and opponents as Zelenaši (Greens). While the Bjelaši claimed that Serbs and Montenegrins were one people, and as such belonged to one country, the Zelenasi advocated the principle of equality whereby Montenegro should have retained a separate identity. Pavlovic (2003a) argues that the majority of Zelenaši supporters came from so-called Old Montenegro, while the supporters of unification were predominantly from the territories of the Brda and those acquired after the Balkan Wars. The Kingdom of SHS (from 1929 the Kingdom of Yugoslavia) enforced assimilationist policies. It viewed Montenegrins as ethnic Serbs and Montenegro as the guardian of Serbian statehood throughout the period of Ottoman rule.

Yet the division between the population of Montenegro, particularly its political and cultural elites, did not vanish. The same territorial and ideological divisions drove the people of Montenegro into opposing camps during the Italian occupation of 1941. The supporters of an independent Montenegro, the Zelenaši, soon joined the communist Partisans, while the Bjelaši supported Serbian nationalist forces (Chetniks). By 1945 the Chetniks were defeated and the newly established socialist state introduced the policy of 'brotherhood and unity' between all Yugoslav nations. The Federal People's Republic of Yugoslavia, constituted in 1945, had six federal units, and Montenegro was one of them.

\section{State socialism and nationalism}

Most analysts explain the origins of the ethno-political divide in Montenegro either by focusing on 'ancient' history, tracing back the present discord to the seventeenth, eighteenth or even the eleventh century, or alternatively by concentrating solely on the most recent political changes accompanying the 
collapse of communism and wars of Yugoslav succession. Despite their disagreements on the causes of this divide, these accounts regularly ignore or explicitly dismiss the post-World War II period of state socialism as largely irrelevant toward understanding the nature of this divide. The same can be said of many general accounts of communism (Vulliamy 1994; Kaplan 1993), in which the argument holds that the authoritarian state successfully suppressed the politicisation of cultural difference whereby both Serbian and Montenegrin nationalisms were 'frozen' in time and could not develop as they were supposedly held in check by the iron fist of the communist rulers. ${ }^{6}$

It is our contention that, in fact, the opposite was the case: that in order to fully understand and explain the emergence of competing popular nationalisms in Montenegro, one must analytically dissect the structure and workings of the communist state itself. Following in part Gellner (1964, 1983) and Brubaker (1996), ${ }^{7}$ we argue that despite its political invisibility, it was the communist state, more than any of its pre-modern predecessors, that created the institutional tracks and unwittingly laid the foundations for the emergence of both the fully fledged popular nationalist doctrines of Montenegrinhood and Serbdom, as well as the structural contours for the eventual independence of Montenegro. We do not argue that the two nationalisms were exclusively created by state socialism. Obviously, as elite articulated phenomena - evident from our short historical analysis - they were in existence long before the establishment of the communist state. Our argument focuses on the institutional underpinnings of nationalism as a mass phenomenon.

As many scholars of nationalism (Gellner 1964, 1983; Smith 1979; Mann 1993; Anderson 1983) have convincingly demonstrated, the development and ultimate success of a particular nationalist movement requires modernity: standardisation of vernacular languages, high literacy rates, advanced division of labour, articulated 'high' culture, developed infrastructural powers of the state, a substantial degree of state centralisation, universal conscription, mass-scale education, constitutionalism, developed transport and communication systems and some form of 'print-capitalism'. As already indicated, before 1945 Montenegro was lacking in most of these. Although Vuk Karadžić had successfully standardised the Serbo-Croat language in the early nineteenth century, a majority of the Montenegrin population (56.1 per cent) was still illiterate in 1941, with over eighty per cent living in highly underdeveloped rural areas (SGCG 1991). Before the communist revolution, Montenegro was still a staunchly tribal society with almost no industry, few major roads, only one small railroad and little division of labour. As we have seen, the first primary school was established as late as 1834 (Rastoder 2003: 120) and by 1945 there were only a handful of secondary schools with no higher education or any equivalent institutionalised 'high' culture. Although some form of military draft was introduced by Prince Danilo in 1853 with the Cross-bearers army (Krstonosna vojska) and army ranks were established by Prince Nikola in 1870 (Rastoder 2003: 121-2), this was a far cry from a modern, mass-scale professional army. Montenegro had no constitutional 
order or parliament until 1905. Finally, as literacy rates were very low, the first Montenegrin newspaper, Crnogorac (Montenegrin), appeared only in 1871 , so that by the early 1940 s there were too few daily publications and too few regular readers to meet one of Anderson's (1983) basic requirements for the existence of an articulated, mass-scale, nationalist ideology: printcapitalism. Hence pre-communist Montenegro was a traditionalist, agrarian society and as Gellner (1983) makes clear, illiterate peasants do not make good nationalists. Although obviously there were individual nationalist ideologues (such as Jovan Plamenac) and small elite-based Serbian and Montenegrin nationalist circles, pre-communist Montenegro met no elementary structural conditions for the development of nationalist movements in the sociological sense of the word. As Pavlovic (2003b: 86) rightly points out when writing about eighteenth-century Montenegro, 'it was the tribe and not the state/central authority that nearly exclusively provided the mechanisms of horizontal identification for individuals'. In addition to strong tribal attachments and intense regional divides, a much more powerful source of collective solidarity in pre-modern Montenegro was the religious tradition of Eastern Orthodoxy. ${ }^{8}$ On top of that, the first attempts at the politicisation of Montenegrin culture had been interrupted by the 1918 unification.

Hence the communist revolution was a key catalyst for the nationalisation of the masses in two senses: as a structural agent of intensive modernisation and as a generator for the politicisation of culture. From 1945 to 1991 Montenegro was transformed dramatically from a network of rural, agrarian, illiterate and kinship-based clans into a moderately developed, urbanised society with almost universal literacy (over ninety-five per cent) and a vibrant 'high' culture. The machinery of the modern bureaucratic state, together with an elaborate administrative apparatus, was put in place for the first time. The processes of industrialisation and urbanisation intensified to such a degree that by 2003, sixty-two per cent of the population were residing in the urban centres (Jelic 2005: 68), with the great majority working either in industry or service. The industrial sector grew from six per cent in 1945 to thirty-five per cent in 1990 (Rastoder 2003: 137). The infrastructural network of roads, railways and airports was built to sustain an ever-increasing level of travel and communication within the state, the pinnacles of which were the Jadranska magistrala of 1961 (linking the mountainous north and the coastal south) and the Belgrade-Bar railway (1976).

Even more significant was the cultural milieu of the new communist republic in which the true foundations for the nationalisation of the masses were laid - the cultural and educational infrastructure. It was under communist rule that all major Montenegrin cultural and educational institutions were created: the first college (1947), the first university faculty (of economics in 1960), the first full-fledged university (in 1974), the Institute of History (1948), the State Archive (1951), the National Theatre (1953) and the Montenegrin Academy of Arts and Sciences (1973) (Rastoder 2003: 137). This period was also witness to a dramatic expansion in mass media: while there had been only 
one radio station broadcast and four newspapers published in 1947, by 2003 there were thirty-two newspapers, thirty-one radio stations, and thirteen TV stations (SP 1985: 217, SG CG 2004: 187-9). Thus the communist era was the most important period of modernisation for Montenegrin society, creating indispensable conditions for the potential transformation of "peasants into Montenegrins'. But while the conditions were ripe, the trajectories that the nation-formation processes took in Montenegro were different from those envisaged by Gellner $(1983,1997)$ or Brubaker (1996). Instead of a single path to nationhood, the modernisation processes created two competing forms of nation-ness - Montenegrin and Serb. Why this particular outcome? To answer this question, we must address the second issue: the state-induced politicisation of culture.

Although an integral part of the Yugoslav federation, Montenegro had its own constitution (since 1946) and, as with other Yugoslav republics, a considerable degree of political autonomy. Due to the gradual decentralisation of power from the federal centre to individual republics, which culminated in the adoption of the 1974 semi-confederal Yugoslav constitution, the state's constitutional independence only increased. ${ }^{9}$ So by the late $1980 \mathrm{~s}$, the state elite had full control over the economy, finances, education, media, policing, jurisprudence, social services and even civil defence. As with other Yugoslav republics, Montenegro was a state within a state, pursuing its own geopolitical goals and socio-economic policies. What made it different from the other republics, and what was decisive to its delayed calls for full independence, are two sets of events both of which were rooted in its state socialist past.

First, to avoid any traditional political divides, the communist state nominally kept the ethno-national categories of Serb and Montenegrin as ambiguous as possible, papering them over with a supposedly trans-national Yugoslavism. ${ }^{10}$ Although the existence of Montenegrin statehood was not questioned, the idea of Montenegrin nationhood remained vague and unclear and this was fully reflected in Montenegro's institutions of high culture whereby some organisations such as the Academy of Arts and Sciences were politically more Serbophile, while others such as the Association of Montenegrin Writers, or Pen Club, were more Montenegrin. However, much more important was the fact that this institutional ambiguity was founded on the principle of not opposing the categories of Serb and Monetengrin, and keeping the three forms (including Yugoslav) of collective attachments deeply inclusive of one another. As a result, a majority of the population went along with this elusive understanding of Montenegrin-ness, whereby for some being Montenegrin implied a distinct sense of nationhood while for others it was no more than a regional designation. The fact that all state censuses indicated that an overwhelming majority declared themselves Montenegrin (in 1961 81.3 per cent, in 198168.65 per cent and in 199161.86 per cent) while only a very small minority saw themselves as Serbs (in 19613 per cent, in 19813.32 per cent and in 19919.34 per cent) (SG CG 2004; Woodward 1995) ${ }^{11}$ is less of 
a reliable indicator of the intensity of national identification and more a blasé symptom of this institutionalised ambiguity. In other words, as long as the notions of Serbian-ness and Montenegrin-ness were not in any direct conflict, declaring oneself vaguely as Montenegrin did not necessarily imply that one was not also a Serb. The main reason behind this state-sponsored ambiguity was the intention to transcend all historical political splits within Montenegro.

Most of these historical cleavages converged on the same axis of polarisation, often including members of the same family or 'tribe' (Greens versus Whites, secular versus orthodox, North versus South, Russophiles versus Westernisers, traditionalists versus modernisers), and culminating in fierce ideological clashes between those who supported Tito or Stalin in their 1948 break-up. ${ }^{12}$ Before communist modernity, the designations 'Serb' or 'Montenegrin' had little meaning in terms of diverse cultural content, as the major historical cleavages were purely political. However, the fact that so many political divides congregated around the two distinct groupings created a structural condition, underpinned by the modernising and hence nationalising state, whereby political divides gradually acquired culturally diverse content. In other words, despite its normative commitment to internationalism and the Yugoslav transnationalism of 'brotherhood and unity', the state's organisational structure unwittingly provided for the gradual institutionalisation and crystallisation of political cleavages into future ethno-national divides. And this leads us to the second set of events: the replacement of the nationalising Montenegrin state elite with Milošević-installed, pro-Serbian cadres in 1989. It is these events more than anything else that temporarily derailed the process of nationalisation of the masses in the direction of Montenegrin nationhood.

Utilising popular dissatisfaction with the existing leadership and the profound economic crisis of the 1980s that almost paralysed the Montenegrin economy - with unemployment rising to twenty-four per cent (Woodward 1995: 33; Bieber 2003) - the new Milošević-supported cadres were installed in power. Organising mass demonstrations of workers, this new political elite managed to successfully channel popular social discontent into Serbophile ethno-nationalism, whereby demonstrators 'came as workers and went home as Serbs' (Đukic 1994: 109). This so-called 'anti-bureaucratic revolution' was the first articulated and sustained attempt to employ the already established and institutionalised structural mechanisms in order to politicise culture and to initiate ethno-nationalist mobilisation of the masses. Drawing on the traditional cultural/religious similarity with Serbia, which was now enhanced by the Kosovo conflict (depicting Albanian rebellion and Slovenian sympathy with it in ethno-cultural rather than political terms), the new rulers were in a position to radically politicise ethno-culture. Initially, with the strong presence of the culturally distinct Other, this movement maintained much of the previous Serb-Montenegrin-Yugoslav ambiguity. Even though, with the wars in Croatia and Bosnia, 'the Other' gradually shifted from Kosovo Albanians and Slovenes to the Croats and the Bosnian Muslims, so long as its presence was maintained the Montenegrin alliance with Serbia remained solid. In other 
words, the institutionally created conditions for ethno-mobilisation were in place and the geopolitical environment shaped the content of this process.

However, once this external 'threat' was removed and geopolitical conditions changed, the movement, together with its main individual protagonists, ${ }^{13}$ gradually split in two - Serbian versus Montenegrin. That is, as long as Serbianism was not in direct opposition to Montenegrin-ness the two forms of individual and collective attachment went largely hand-in-hand. Once the situation changed, the two found themselves on a collision course. With the first modern mass-scale open clash between Montenegrinhood and Serbdom in the late 1990s, the population of the state had crossed the nationalising Rubicon by eradicating most of the previous ambiguity and by attempting to 'fix' their ethno-national attachments 'once and for all'. Although nominally initiated by the political elites, the conflict between Serbianism and Montenegrin-ness in Montenegro was a direct outcome of the changing geopolitical environment whereby the union with Serbia was proving politically and economically dysfunctional, beset by the constant threat of Serbia's domination over its ten-times smaller partner and the radically differing regional and geopolitical interests of the two republics. Serbia's increasing isolation, its unwillingness to reform under Milošević, its war with NATO over Kosovo, its reluctance to cooperate with the International Criminal Tribunal for the former Yugoslavia (ICTY) even under its democratic government, have all had detrimental effects on Montenegro's development and its ambition to join Euro-Atlantic integrations. In this context, the geopolitical raison d'Etat has further enhanced the already institutionalised politicisation of culture, thus directly influencing the perceptions of the Montenegrin political and cultural elites and population at large in the direction of favouring an independent state. To justify independent statehood it became paramount to articulate political goals in cultural terms and hence to counter Montenegrin-ness and Serbianism. The staggering change in public opinion on the question of national self-determination between the two referenda (in 1992 and 2006) is a result of many factors but most of all the legacy of communist modernity, its politicisation and institutionalisation of high culture and state-building which were all underpinned by the dramatic geopolitical transformations of recent years.

This remarkable social change was also evident in the results of the recent census. While in the communist era an overwhelming majority of the population declared themselves as Montenegrins and only a small minority as Serbs, in 2003 this shifted to a staggering 31.99 per cent Serbs to 43.16 per cent Montenegrins (SG CG 2004: 54). Once the two nation-building projects underpinned by the two distinct national ideologies come into direct confrontation, the population was forced to opt for one over the other. It is not only that being a Montenegrin and a Serb now for the first time entails a sense of almost complete mutual exclusion, but it also implies a commitment to conflicting state-building projects. Although the striving for independent statehood and nation-building are two distinct processes, they are tightly 
linked together. This is not to say that with the 2006 referendum the process of nation-formation in Montenegro is concluded and that Montenegrin and Serb identities are now carved in stone. Far from it, it is global and regional geopolitics, economic development, the infrastructural power of the new state, and the actions of its political and cultural elites and civil society groups that will determine in which direction the processes of nation-formation will unfold.

In summary, prior to communist modernity the collective designations of Serb/Montenegrin/Slav/Yugoslav/Orthodox, together with their sense of group attachment, were not in conflict with each other, but rather were overlapping, ambiguous and mutually inclusive forms of group membership. It was the modernising communist state that provided the institutional channels for the future crystallisation of these group categories into distinctive forms of individual and collective attachment. The communist state supplied the institutional form and structural conditions for the ethno-national mobilisation of the masses, but it was the change in geopolitics that had the decisive impact on the content of this mobilisation. Once the geopolitical environment changed and raison d'Etat took over, the two nationalisms found themselves in open confrontation. It is these processes that ultimately put an end to any previous ethno-national ambiguity, making clear who was Serb and who Montenegrin.

The impact of communist modernity on the creation of the national high culture, and eventually on the nationalisation of the masses, together with geopolitical changes, tells us a great deal about the structural causes of the two different nationalist trajectories. However, more exploration is needed into the form and content of these divergent national attachments. In other words, what are the current dominant discourses of national identification in Montenegro?

\section{Who are the Montenegrins?}

As has already been indicated, the first conflict over definitions of Montenegrin-hood occurred with the first wave of intensive institutionalisation of the Montenegrin state during the latter half of the nineteenth century. This division acquired symbolic colours in 1918 - Greens versus Whites - which still paint the political landscape of Montenegrin society today, almost a hundred years later. Over the course of this period Montenegro has been an independent Kingdom, a province of the Kingdom of Yugoslavia, a Republic within Socialist Yugoslavia, and a Republic in Milošević's remnant of Yugoslavia. It briefly reappeared in the title of the state entity of Serbia and Montenegro, and, since the referendum of 21 May 2006, effectively came full circle when Montenegro was proclaimed an independent state. The results of the referendum in which 55.5 per cent voted for independence and 44.5 per cent against clearly illustrated the degree of polarisation between Montenegrin citizens. 
In this section we will analyse the debate that took place in the wake of the Referendum, primarily in the mass media where the main protagonists were, aside from the journalists themselves, the leaders of the main political parties, prominent intellectuals, and members of the cultural elite. The analysis will highlight the differences in perceptions within the Montenegrin nation between the supporters of independence and those who opposed it. We hope that this analysis will reveal how the definition of Montenegro as an independent nation was influenced by the structural and cultural changes that characterised the end of the twentieth century in these territories.

\section{Montenegrins as ethnic Serbs}

Along with the disappearance of an independent Montenegro from the political map in 1918, any definition of the Montenegrins as an authentic nation disappeared from the public discourse. Monarchist Yugoslav political and cultural institutions propagated a view according to which Montenegrins were seen as ethnic Serbs. The 2006 referendum revived this argument.

Anthony Smith (2003: 15) defines an ethnie or ethnic group as 'a named community of shared origin myths, memories and one or more element(s) of common culture, including an association with a specific territory'. While we doubt that the proponents of the above view ever encountered Smith's writings, the stream of their argument follows such a definition. The bloc that opposed the independence of Montenegro - the No Bloc - defined Montenegrins on the basis of a common name, history, myths of origin, culture, religion and territory with the peoples of Serbia and Montenegro.

The most prominent argument aimed at supporting the view that Montenegrins were ethnically Serb was that of a common name. Peter Vlahović (www.njegos.org/past/Vlahovic.htm) offers some of the clearest examples: 'Even when they called and declared themselves as Dukljani, and later as Zečani, and finally as Montenegrins ... they always had another common name - Serbs, and declared themselves so.' Indeed, there is no problem in finding historical records that fully support such a claim. Vlahovic refers, among others, to the Charter of King Milutin from the fourteenth century and to the Monastery of St Nicholas where the people of the region are described as Latins, Albanians, and as Vlachs. Vladika Danilo (1670-1735) apparently left a note in which he called himself 'the prince of the Serbian land'. Similarly, Bishop Vasilije Petrović (1709-66) signed himself as 'Serene metropolitan of Montenegro, Skenderia, the Littoral and of the Serbian throne' (ibid.). In 1807, Vladika Petar I Petrović Njegoš wrote about how 'the leading role in the restoration of the Serb empire belongs to Montenegro' (ibid.). Petar II Petrović Njegoš declared in 1848 that Serbdom had to unite, and in 1855 Danilo Petrović Njegoš proclaimed a code that would come to be recognised as one of the first all-Montenegrin laws known as The Code of Prince Danilo. In its 92nd paragraph was written: 'there is no other nationality 
in this land except the Serb nationality and no other religion except Eastern Orthodoxy' (www.njegos.org/petrovics/danilo.htm).

Records such as these were uncovered by current daily newspapers and presented as evidence of a Montenegrin Serb identity. For example, during the period of 18-20 May 2006, the pro-No Bloc paper Dani printed a series of articles entitled Historical Lessons in which the letters of King Nikola were used to demonstrate the national identity of this last Montenegrin king. The message was emphasised in the title: 'Serbs in origin, Montenegrins by territory'.

These references to the writings of Montenegrin rulers can only be seen as an attempt to establish historical continuity between the Montenegrins of old times and those of today. If the forefathers declared themselves to be Serbs, their descendents cannot be anything else. According to this view, history is not seen as just a set of records - dead letters. History is perceived as a living thing. It determines the present and shapes the future through the notion of predecessors. These predecessors are seen as the guardians of Montenegrin honour, their system of values. The reports of the Dani newspaper frequently referred to the speeches and statements of those who did not support Montenegrin independence, political leaders as much as 'common' people. The justification for their attitudes was found in their heritage. For example, in its 18 May 2006 issue, Dani quoted Andrija Mandić - leader of the Serbian People's Party in Montenegro - who claimed: 'All who vote other than NO will embarrass their descendents as well as their predecessors'. In the same issue the 'head' of the family Bogavac from Mojkovački Tutići stated: 'in [this community's] foundations bones of my father and other predecessors are built in and their curse would reach me if I would vote for an independent Montenegro'. Čedomir Janketić said: 'We have always been Serbs and we will stay Serbs. I would be ashamed in front of my predecessors if I did differently, and for my descendents I would always be a disgrace.'

Past, present and future are seen here as an organic whole, a link strengthened not only by nature but by nurture as well. People of one blood, the brothers, are also of the same religion, the same traditions, and the same language. The Socialist People's Party (SNP) reinforced this in a number of its party resolutions. For example, one entitled 'The declaration on preservation of state, spiritual and democratic values' put forward on 11 November 2005 states: 'The Serbian language is one of the essential factors of a Montenegrin entity. Within it our spirituality and history is preserved, and hence, violence against the Serbian language represents an attack on the highest values of Montenegro' (www.snp.cg.yu). Similarly, the party's congress put forward the 'Resolution on the [Serbian Orthodox] Church' (ibid.). The specific nature of the Orthodox Church structure merges the issues of religion and nationality. An autocephalous church becomes proof of the existence of a nation. The SNP writes of how the 'Metropolitanate of Montenegro and the Coastlands [is] spiritually the highest and historically the most important part of the Serbian Orthodox Church' (ibid.). Consequently, through the protection of the de facto Serbian 
Orthodox Church, 'its spiritual institutions and holy relics, Montenegro will be sustained in the best possible way, its history and its tradition'.

But even if Montenegrins are Serbs - ethnically and historically, by language and faith - proponents of these views still have to explain the existence of the terms Montenegro and Montenegrins. The opponents of Montenegrin independence see Montenegro as a territorial region of Serbdom. The notion of regional difference is balanced with the historical territorial demarcation of the Montenegrin tribes. Dani of 18 May 2006 printed a report from a gathering of the tribe Kuči in which a political leader claimed: 'If we follow the reasoning of the Montenegrin government, which only wants to separate, it could happen that Kuči demands independence from the rest of Montenegro. We would have a basis for declaration of independence for Kuči, our flag would be the one from the battle of Fundin, and the border with Podgorica would be the cinema Kultura.' This example shows how ethnicity is viewed as the basis of national definition. Thus if ethnic origins are marginalised, according to this view, there is no objective foundation to national identification. The possibilities of territorial fragmentation are limitless.

Where then did the idea of Montenegrins as a separate nation originate? The explanation is found in the attempts at social engineering by communist Yugoslavia that were apparently undertaken for one reason only: to weaken the Serbian nation. The most commonly mentioned 'conspirator' is Milovan Đilas. After all, Dani would claim, it was his decision as a member of the CPY leadership that enabled the establishment of the Montenegrin Republic within Socialist Yugoslavia. The institutionalisation of this republic on a political, cultural and economic level, and the propaganda that followed, were seen as artificially creating a new sense of identity that had as its primary aim the separation of Montenegrins from Serbs.

The proponents of Montenegrin independence rejected such a view. It was not the socialist revolution that created the Montenegrin nation, but rather historical evolution.

\section{Montenegrins as a civic nation}

If the definition of Montenegrins as ethnic Serbs resembles that of Smith, the view according to which Montenegrins are a nation on their own accord closely resembles the definition of nationhood proposed by Ernest Gellner (1983: 7). The daily newspaper Pobjeda (http://www.pobjeda.co.yu) printed over several issues excerpts from Mijat Sukovićs book entitled The Constitution of Montenegrin Principality from 1905. Here Šuković explains:

Unlike others, the Montenegrin nation has not formed its state, but, rather, within the Montenegrin state, through the process of modernization at the end of the nineteenth and beginning of the twentieth centuries, the maturation and the final configuration of the Montenegrin nation was achieved (www.pobjeda.co.yu/naslovna.phtml?akcija $=$ advview\&id $=78144$ ). 
In the wake of the referendum of 2006, in order to base the Montenegrin nation on sound ground and challenge any notion of the artificiality of its origins, proponents of an independent Montenegro undertook the task of proving the existence of a Montenegrin nation prior to the establishment of Yugoslavia. Hence the impact of state socialism on the formation of the Montenegrin nation is conspicuously missing from these debates. The history of the Montenegrin nation is seen as having been interrupted by the formation of the so-called First Yugoslavia. Only the reestablishment of an independent state of Montenegro will restore the 'natural' life of the nation.

As Suković explains, the Montenegrin nation at the end of the nineteenth and the beginning of the twentieth centuries 'naturally developed its maturity and was formed on a solid and centuries-long Montenegrin historicalcultural and historical-political factual basis, in which all, absolutely all, constituent elements have already existed' (ibid.). Unlike the opponents of Montenegrin independence and nationhood, who define the nation in exclusively ethnic terms, the proponents of Montenegrin independence see the state and its institutions as the main factors that initiated the formation of the Montenegrin nation.

History once again provides adequate support for these views. In this case, the proponents of Montenegrin independence produced official communications from the beginning of the twentieth century. Even if generations of Petrovic rulers saw themselves as Serbs, the formation of the Montenegrin Kingdom reformed the ruler's mode of identification. Šuković emphasised how 'instead of ... using terms such as "Serbdom", "Serbian people [narod]", "interests of Serbdom", in official communications with Serbia, other terms appeared - "two brotherly people [narodi] Serbian and Montenegrin", separate "interests of Montenegro and Montenegrin people", (ibid.). The stress placed by the opponents of Montenegrin independence on historical continuity forced the Yes Bloc to emphasise significant moments of historical discontinuity. The events of 1918, during which Montenegro became a part of a unitary Yugoslavia, ${ }^{14}$ are now regarded as the crucial moment of suppression of Montenegrin nationhood, seen as having been orchestrated by the Serbdominated government. The last and only king of Montenegro, Nikola, becomes a heroic and tragic character symbolic of Montenegrin suffering. It now became important to demonstrate Nikola's Montenegrin identity and his opposition to unification. In May 2006, Pobjeda (http://www.pobjeda.co.yu) published a series of excerpts from the book Montenegro and Montenegrins in the New Europe by Branislav Kovačević and Marijan-Mašo Miljić in which the authors examined in detail the events surrounding WWI. They write: 'Before the war, king Nikola wanted his own state, independent from Serbia, and his own crown, independent from Karađorđevic's one'. The sacrifices of the Montenegrin people throughout WWI were, according to this view, 'rewarded' by the destruction of the Montenegrin dynasty and its state. 'The enthronement of the Petrovic dynasty is executed not by voting but by the blood of the 
best elements in Montenegro, those who in spite of the most terrible temptations defended their honour and freedom, and the freedom and unity of their people.' The message was simple: the Kingdom of Montenegro was an independent state and an expression of Montenegrin nationhood at the beginning of the twentieth century. The formation of an independent Montenegro a century later will, again, secure the existence of the Montenegrin nation.

The argument of the No Bloc, according to which only a minority of Montenegrin inhabitants declared themselves to be Montenegrins, was balanced by a noteworthy definition of nationhood by Šuković. He writes:

Nation is an objective category and phenomenon. Its existence does not depend on the number of people that belong to it. ... The existence of the Montenegrin nation in that period is attested by objective facts. .. . They have fully formed Montenegrin historical, political, cultural, national identity and individuality.

The existence of a nation defined in this way does not depend on identification by its individual members. It exists so long as the 'spirit' of the nation exists. The nation is seen as a metaphysical phenomenon, a 'spirit', not a social group, safeguarded by the state institutions. As a consequence, the essence of the Montenegrin nation is changeable, not given. Sreten Zeković, in an article entitled Montenegrinhood and Montenegrin Serbdom (www.montene gro.org.au), exemplified this view when stressing the importance of 'non-ethnic, supra-ethnic and multi-ethnic' factors in the formation of Montenegrin-hood through the course of history. He recognised the influences of 'Serbian consciousness and tradition', especially 'Serbian Orthodoxy', but also the influence of the Western European tradition just as that of Islam. These factors that have affected Montenegrin consciousness throughout history, he concludes, formed a never-accomplished Montenegrin national phenomenon.

The definition of the Montenegrin nation at the beginning of the twentyfirst century was clearly a reaction to the view that denied this nation's existence. One of the most noticeable characteristics of this definition was a clear break with the tradition of defining the nation on these territories. The dominant ethnic, organic definition was replaced by a civic definition that emphasised the role of the state in the process of nation-building. The notion of the nation as built from below was replaced by one in which it is seen as built from above. Such a view is possible only in a situation where the institution of the state is perceived as national and therefore capable of disseminating the 'spirit' of Montenegrin-hood. The Montenegrin 'national-awakeners' of today deny the role of Socialist Yugoslavia in 'forging the Montenegrin nation'. Yet they rely on the structural support of the Montenegrin state and its cultural, political, and educational institutions, which were essential in turning the Montenegrin people into a Montenegrin nation. 


\section{Conclusion}

In the context of the complete failure of communist federal structures worldwide, the delayed independence of Montenegro was and remains an oddity. While the small size of the state, its questionable economic viability, its lack of serious political alternatives and its strong cultural and historical links to Serbia explain an important segment of this puzzle, these factors alone do not provide the full picture. A more substantial interpretation requires engagement with a crucial but often neglected issue - the legacy of communist modernity. While most scholarly accounts, as well as the dominant Montenegrin nationalist discourse, either ignore or minimise this historical period, even those interpretations that do highlight the importance of state socialism in nation-building, such as the Serbian nationalist discourses in Montenegro, misinterpret its impact. The two divergent trajectories of nation-formation in Montenegro had little to do with the deliberate social engineering of communist leaders such as Đilas and others, but rather were largely an unintended consequence of intensive state-building, cultural and political modernisation, and most of all, the gradual politicisation and institutionalisation of high culture. The communist state provided institutional structures and organisational mechanisms that helped to reify ethno-national attachments. In this respect, Montenegro was similar to the other republics of federal Yugoslavia which all, in some aspects, reflected the Soviet policy of nationality. However, what made Montenegro unique was its turbulent history of numerous territorially based political divides. To circumvent the deep historical cleavages between the North and South, Greens and Whites, or traditionalists and modernisers, the communist state was forced to balance the nationalisation of the masses along the Montenegrin-Serb axis by keeping the two categories ambiguous and inclusive while integrating them with the broader Yugoslav identity. Although the collapse of the Yugoslav state dented this balance, it was only the radical shift in geopolitics during the late 1990s and early 2000s that pitted Serbian and Montenegrin nationalisms against each other and proved to be the final catalyst for the eventual independence of Montenegro. Thus Montenegrin nationalism was not a simple fabrication either of 'Serbophobic conspirators' or 'totalitarian dictatorship'. Instead both nationalisms, Montenegrin and Serbian in Montenegro, were products of the same complex institutional process - communist modernity.

Thus the answers to the three questions raised in the introduction point in the same direction. The peculiarity of Montenegro's nation-formation and the delayed support for full independence was rooted in the cultural and political ambiguities of state socialism. The astounding change in popular support for a sovereign and internationally recognised nation-state emerged only when this ambiguity was ultimately broken and Serbian and Montenegrin nationalisms found themselves on a direct collision course. Finally, these same processes have helped to institutionalise and mobilise the Montenegrin public 
around the two dominant and opposing discourses of nationhood: the view of Montenegrins as ethnic Serbs and the notion of a distinct Montenegrin civic nation. The slight majority won by the pro-independence bloc has secured an independent state and thus moved the debate away from the question of the usefulness of the existing union with Serbia. However, the process of nationbuilding is far from uniform or complete as the two contradictory understandings of 'Who are the Montenegrins?' will remain to polarise the population of Montenegro in the years to come.

\section{Notes}

1 We would like to thank the anonymous referees of Nations and Nationalism for their helpful comments on the earlier draft of this paper.

2 We use terms such as 'deferred' or 'belated' independence in a purely chronological and comparative sense without any intention of implying that this particular historical outcome was inevitable or something that we personally prefer.

3 Out of the influential political parties that emerged in the early post-communist period, nearly all of them had direct or indirect links with the communist-era establishment. Even the Liberal Alliance of Montenegro, which was the only significant pro-independence force in the early 1990s, was headed by a former communist, Slavko Perović.

4 Although the historic designation hristiani or hrišćani (Christians) was vastly ambiguous when used in the context of a religious in-group (thus often acting as a synonym for Serb, Montenegrin or a tribal label) it was much less ambiguous when used for the religious Other (i.e. Catholic or Muslim) when it become a mutually exclusive category of identification.

5 According to Rastoder (2003: 110) and Jovanović (1948: 55), the term Montenegro (Crna Gora, literally 'Black Mountain') would become the standard name for the territory of the mountainous area between the coast and the Zeta River around the end of the fifteenth century and would be known as Old Montenegro. The north part of the Zeta River was known as the Brda. Full unification of these territories occurred only in the nineteenth century.

6 This view also underestimates the significant bifurcations in political life under state socialism. For a criticism of this perspective see Malešević (2006: 158-63).

7 Although we find Brubaker's (1996, 2004, 2006) general institutionalist account highly convincing we do not subscribe to his cognitivism that attributes too much power to the 'pervasive system of social classification'. Similarly, we draw on Gellner's modernist emphasis on the standardised high culture, universal literacy, and education systems while dissenting from his explanatory economism. Furthermore, unlike these two authors, we stress the importance of geopolitical factors in the development and articulation of distinct nationalist movements and ideologies.

8 For a cogent analysis of the importance of Orthodox Christianity in the formation of nationalisms in the Balkans see Roudometof (2001).

9 On the nature of Yugoslav federalism see Ramet (1992) and Malešević (2006: 157-84).

10 For a representative writing that expresses an official party line on nationalism in Montenegro which also reproduces this ambiguous attitude see Spadijer (1986).

11 As in the 1961 census the category 'Muslim' was not listed as distinct nationality, most Muslims of Montenegro declared themselves as Montenegrins.

12 On the unprecedented intensity of this conflict in Montenegro, see Banac 1988.

13 In 1997 the ruling DPS split into two political parties, led by two former leaders of the 'antibureaucratic revolution' in Montenegro - the DPS led by M. Đukanović and the SNP led by M. Bulatović.

14 Actually, in 1918 the official title of the state was the Kingdom of Serbs, Croats and Slovenes, and it became Yugoslavia only in 1929. 


\section{References}

Anderson, B. 1983. Imagined Communities: Reflections on the Origins and Spread of Nationalism. London: Verso.

Banac, I. 1988. With Stalin against Tito: Conformist Splits in Yugoslav Communism. Ithaca, NY: Cornell University Press.

Bieber, F. 2003. 'Montenegrin politics since the disintegration of Yugoslavia', in F. Bieber (ed.), Montenegro in Transition: Problems of Identity and Statehood. Baden-Baden: Nomos.

Boehm, C. 1983. Montenegrin Social Organisation and Values. New York: AMS Press.

Brubaker, R. 1996. Nationalism Reframed: Nationhood and the National Question in New Europe. Cambridge: Cambridge University Press.

Brubaker, R. 2004. Ethnicity without Groups. Cambridge, MA: Harvard University Press.

Brubaker, R. et al. 2006. Nationalist Politics and Everyday Ethnicity in a Transylvanian Town. Princeton, NJ: Princeton University Press.

Đukić, S. 1994. Između slave i anatme: Politička biografija Slobodana Miloševića. Belgrade: Filip Višnjić.

Đurić, D. 2003. 'The economic development of Montenegro', in F. Bieber (ed.), Montenegro in Transition: Problems of Identity and Statehood. Baden-Baden: Nomos.

Gallagher, T. 2003. 'Identity in flux, destination uncertain: Montenegro during and after the Yugoslav wars', International Journal of Politics, Culture and Society 17, 1: 53-71.

Gellner, E. 1964. Thought and Change. London: Weidenfeld and Nicolson.

Gellner, E. 1983. Nations and Nationalism. Oxford: Blackwell.

Gellner, E. 1997. Nationalism. London: Phoenix.

Jelić, S. 2005. 'Poljoprivreda i ruralni razvoj u Crnoj Gori', in Multifunkcionalna poljoprivreda $i$ ruralni razvoj. Conference Proceedings. Belgrade: Institute for Agricultural Economics.

Jovanović, J. 1948. Stvaranje crogorske države i razvoj crnogorske nacionalnosti. Cetinje: Narodna knjiga.

Kaplan, R. 1993. Balkan Ghosts: A Journey through History. New York: St. Martin's Press.

Malešević, S. 2006. Identity as Ideology: Understanding Ethnicity and Nationalism. New York: Palgrave Macmillan.

Mann, M. 1993. The Sources of Social Power: Rise of Classes and Nation States, 1760-1914, Vol. 2. Cambridge: Cambridge University Press.

Pavlović, S. 2003a. 'Literature, social poetics, and identity construction in Montenegro', International Journal of Politics, Culture and Society 17, 1: 131-65.

Pavlović, S. 2003b. 'Who are Montenegrins? Statehood, identity, and civic society', in F. Bieber (ed.), Montenegro in Transition: Problems of Identity and Statehood. Baden-Baden: Nomos.

Ramet, S. 1992. Nationalism and Federalism in Yugoslavia. 1962-1991. Bloomington, IN: Indiana University Press

Rastoder, S. 2003. 'A short review of the history of Montenegro', in F. Bieber (ed.), Montenegro in Transition: Problems of Identity and Statehood. Baden-Baden: Nomos Verlagsgesellschaft.

Roudometof, V. 2001. Nationalism, Globalization and Orthodoxy. Westport, CT: Greenwood Press.

Rovinski, Pavel A. 1998 [1897]. Etnografija Crne Gore. Podgorica: CID.

SG CG. 1991. Statistički godišnjak Crne Gore. Titograd: Zavod za Statistiku Crne Gore.

SG CG. 2004. Statistički godišnjak Crne Gore. Podgorica: Zavod za Statistiku Crne Gore.

Smith, A. 1979. Nationalism in the Twentieth Century. Oxford: Martin Robertson.

Smith, A. 1999. Myths and Memories of the Nations. Oxford: Oxford University Press.

Smith, A. 2003. Chosen Peoples: Sacred Sources of National Identity. Oxford: Oxford University Press.

Spadijer, M. 1986. 'Nacionalizam u Crnoj Gori', Socijalizam 4, 1: 111-17.

SP. 1985. Jugoslavija 1945-1985 Statistički Prikaz. Belgrade: Savezni Zavod za Statistiku. 
Vulliamy, E. 1994. Seasons in Hell: Understanding Bosnia's War. New York: St. Martin's Press.

Woodward, S. 1995. Balkan Tragedy: Chaos and Dissolution after the Cold War. Washington, DC: Brookings Institution Press.

Zeković, S. Crnogorstvo i crnogorsko srpstvo, consulted 10 May 2006, <www. montenegro.org. au/crnogorstvo_i_crnogorsko_srpstvo.html>

\section{Websites}

www.dan.cg.yu

www.monitor.cg.yu

www.montenegrina.net

www.montenegro.org.au

www.njegos.org

www.pobjeda.co.yu

www.snp.cg.yu 